\title{
Effect of Interest Rates on Deposit Money Banks' Profitability in Nigeria
}

\author{
Ilugbemi, Albert O* \\ Department of Banking and Finance Federal Polytechnic, Ado, Ekiti State, Nigeria
}

\section{*Corresponding Author}

Ilugbemi, Albert $\mathrm{O}$

\section{Article History}

Received: 16.07 .2020

Accepted: 24.07 .2020

Published: 26.07.2020

\begin{abstract}
This study examined the effect of interest rates on the profitability of Deposit Money Banks in Nigeria between 2004 and 2018. The time series data for this study were collected from the Central Bank of Nigeria Statistical Bulletin and the annual reports of Nigerian Deposit Insurance Corporation. The study employed inferential statistics by analyzing the collected data via ordinary least square multiple regression technique. The choice of this technique was sequel to the Augmented-Dickney-Fuller Unit Root test which confirmed the stationarity of the research variables at levels. Findings from this study revealed that all the explanatory variables i.e lending interest rate (LINT), monetary policy rate (MPR), treasury bill rate (TBR) and ratio of cash balance to total liabilities maintained positive but insignificant relationships with the Return on assets of Nigerian banks (ROA); also, the coefficient of determination $\left(\mathrm{R}^{2}\right)$ of 0.32 indicated that about $32 \%$ of the variation in the profitability could be explained by the interest rate proxies. Based on these findings, it was concluded that lending interest rate was an insignificant determinant of Deposit Money Banks' profitability in Nigeria and recommended that Banks must strike a good balance in their loans pricing and investment decisions as this will help them to cover cost associated with lending while maintaining good banking relationship with their customers.
\end{abstract}

Keywords: Interest rate, money deposit bank, profitability.

\section{INRODUCTION}

Banking, like other sectors of the economy exists primary for the purpose of making profit and maximizing the wealth of their shareholders. In order to fulfill this mandate, banks must strive to generate enough incomes to cover their operating costs and at the same time, leaves some margin as profit for the compensation of various stakeholders in the sector, of which shareholders are very notable. While trying to generate incomes, the larger chunk of their incomes is expected to come from interest charged on loans and advances given to their numerous customers, among other sources. Thus, interest, whether lending, saving or other interest payable and receivable by banks in the ordinary course of their business determines at from time to time the profitability level of banks, and by extension, the banking sector. Sequel to the liberalization of the financial sector in 1986, interest rate directions and movements have been left to vagaries of the forces of demand and supply and this of course, has engendered fluctuations in the incomes made by banks and by extension, the banking sector. Interest rate in Nigeria, and perhaps, all over the world is being determined from time to time by various factors because despite the liberalization of the Nigerian financial sector, the sector is not left to operate on auto-pilot but being guided from time to time by the Central Bank of Nigeria through their monetary policy instruments.

Interest rate also determines many things in the economy and play a significant role in the availability of credit to the various sectors of the economy. Needless to say that high interest rate will discourage borrowing by the various economic agents, and thus, economic growth may suffer while low interest rate will encourage borrowing by these sectors for productive purposes which support the growth of the economy. In the Banking is an economic activity, which deals with the intermediation of funds between the surplus units and the deficit units of an economy and all the channeling of such resources to profitable investments. Banks also facilitate the provision of an efficient payment system. Therefore, interest rates have remained a subject for critical assessment with diverse implications for savings

Copyright @ 2020: This is an open-access article distributed under the terms of the Creative Commons Attribution license which permits unrestricted use, distribution, and reproduction in any medium for non commercial use (NonCommercial, or CC-BY-NC) provided the original author and source are credited. 
mobilization and investment promotion. Generally, interest rates are the rental payments for the use of credit by borrowers and return for parting with liquidity by lenders. In the Nigerian economy, the minimum rediscount rate (MRR) now monetary policy rate (MPR) is the official interest rate of the Central Bank of Nigeria (CBN), which anchors all other interest rate in the monetary market and the economy. Nigerian deposit money banks are crucial channels for transmission of CBN's interest rate in Nigeria. This is because of the intermediation role which banks play in resource mobilization and allocation. Banks pay interest on deposit on one hand and on the other hand they charge interest on loans and advances lent to borrowers. The difference between these two interest rates defines the interest spread which constitutes a significant proportion of the profits of Nigeria money deposit banks. Thus, interest rate unavoidability is an important factor in the survival of Nigeria money deposit banks especially as it concerns their profitability. As interest rate keeps on changing as can be seen from the unstable interest rate regime in Nigeria, such frequent changes could affect banks' overall profitability which in turn, could have impact on the general economy of a country. In other words, the profitability of the banking sector might become a function of changing interest rates. It thus, becomes imperative to investigate the effect of interest rates over the years as related to the profitability on the deposit money banks in Nigeria.

\section{OBJECTIVES OF THE STUDY}

The main objective of this study is to examine lending rate in the Nigerian money deposit banks and its effect on banks profitability, while the specific objectives are:

- To examine the effect of lending interest rate on Nigerian money deposit banks' profitability.

- To investigate the effect of monetary policy rate on profit made by money deposit banks in Nigeria.

- To find out the effect of treasury bill rate on deposit money banks' profitability in Nigeria

\section{Research Questions}

- What is the effect of lending interest rate on Nigerian money deposit banks' profitability?

- What is the effect of monetary policy rate on profit made by money deposit banks in Nigeria?

- What is the effect of Treasury bill rate on deposit money banks' profitability in Nigeria?

\section{Research Hypotheses}

The following statements of hypotheses are conjectured for this study:

- $\mathrm{HO}_{1}$ : Lending interest rate has no significant effect on the return on assets of Nigerian banks;

- $\mathrm{HO}_{2}$ : Monetary policy rate has no significant effect on return on assets of Nigerian banks.

- $\mathrm{HO}_{3}$ : Treasury bill rate has no significant effect on the return on assets of Nigerian banks

\section{LITERATURE REVIEW \\ Conceptual Review}

Lending which may be on short, medium, or long term basis is one of the services that deposit money banks do render to their customers. In other words, banks do grant loans and advices to individuals, business organization as well as government.

In order to enable them to embark on investment and development activities as a means of aiding their growth in particular or contributing toward the economic development of a country in general [1].

Interest rate is the amount of the interest paid percent of time expressed as a percentage of the amount borrowed. The cost of borrowing money, measured in naira, per year per naira, borrowed, is the interest rate. Interest rates differ mainly in term/maturity and liquidity together with the factors is considered many different financial instruments and so many different interests' rates will emerge [14].

Interest rates can either be nominal or real. Nominal interest rate measures the yield in naira per year, per naira, invested while the real interest rate is corrected for inflation and is calculated as the nominal interest rates minus the rate of inflation [2].

\section{Theoretical Review}

The theoretical framework for this study is adapted from [3], which tries to factor the degree of opened of an economic in the analysis of the influence of both interest and external factors of interest ratio movement on the profitability in a semi-open economy like Nigeria. Suppose we have a closed economy in which there is no inflow or outflow of capital and the demand for money is the demand for real money. In such economic, money is the held by the economic units purely to finance transactions and increase the demand for money with real output. However, it is worthy of note that, holding money has an opportunity cost that is measured by the nominal rate, of interest, with higher interest rates discouraging the holding of wealth in the form of money. 


\section{Loan Pricing Theory}

This theory is posits that banks should consider the problems if adverse selection and moral hazard since it is very difficult to forecast the borrower type at the start of the banking relationship [15]. If banks set interest rates too high, they may induce adverse selection problems because high risk borrowers are willing to accept these high rates. Once these borrowers receive the loans, they may develop moral hazard behaviour or so called borrowers borrow moral hazard since they are likely to take on highly risky projects or investments [16]. From the reasoning of Stiglitz and Weiss, it is usual that in some cases we may not find that the interest rate set by banks is commensurate with the risk of the borrowers.

\section{Theory of Multiple Lending}

This theory connotes that banks should be allowed to shape lending (Loan syndication) in the presence of welldeveloped equity markets. Banks suggests equity and mergers and acquisition increase banks' lending capacities, thus, reducing their need of greater diversification and monitoring through share lending $[17,18,16]$. Thus theory has a great implication for banks in Nigeria.

\section{Credit Market Theory}

A model of the new classical credit market postulated that the terms of credits clear market. If collateral and other restrictions (covenants) remain constant, The interest rates is the only price mechanism. With an increasing demand for credit and a given customer supply, the interest rate rises, and vice versa. It is believed that the higher the failure risks if the borrower, the higher the internet premium [4].

\section{Empirical Review}

Kanwal and Modern [5] investigated the impact of macroeconomic variables on profitability of public Limited commercial banks in Pakistan for years 2001-2011. Pooled Ordinary Least Square (POLS) method was used to example the effect of 3 major external factors, inflation rate, real gross domestic product (GDP) and real interest rate on profitability indicators, return on assets (ROA), return on equity (ROE) and equity multiplier (EM) ratios in 3 separate models. The empirical findings indicate a strong positive relationship of real interest rate with ROA, ROE and EM. Secondly, real GDP is found an insignificance positive effect on ROA, but an insignificant negative pact on ROE and EM. Inflation rate on the other hand, has a negative link with all 3 profitability measures. Overall, the selected macroeconomic factors are found to have a negligible impact on earnings of commercial banks Road and Megan [19] investigate the impact specific variables. Asset size, Credits Risk, Total Deposits to total assets ratio and macroeconomic indicator interest rate (Discount rate) on the profitability measures. ROE and ROA of commercial banks in Pakistan during the period of 2006-2010. There are two measures of profitability Return on equity (ROE) and Returning assets (ROA). All 32 commercial banks were selected and by using regression the results show that there is a significant impact of bank specific variables asset size, total deposits to total assets, credit risk and macroeconomic indicator (interest rate) on ROE and credit risk and interest rate have also a significant impact on ROA.

Amer, Azlan et al. [11] examined the "Determinants of commercial banks" Return on Asset: panel Evidence from Malaysia" investigated the possible macroeconomic factors that influence the profitability of domestic and foreign commercial banks in Malaysia. They use an unbalanced panel Fraser of 16 commercial banks and panel data regression techniques over the period of 2004-2011.The result indicates that all the external factors namely inflation, interest rate and HDP have a positive impact in all commercial bank's return in assets. They also found that interest rate appears to influence foreign bank's profit positively but shows no impact on domestic banks performance.

Suffian [6] investigated the impact of bank specific and macroeconomic variables on the Korean banking sector during the pre and post-Asian financial crisis. A total of 251 bank year observation consisting of 11 commercial banks over the period 1993-2003 were employed and tested using panel fixed and random effect regression techniques. In regards to macroeconomic perspectives, the result shows that inflation has positive association with banks' return on assets. Super and Amber [7] investigated bank specific and macroeconomic determinants of commercial bank profitability in Turkey over the period of 2002-2010. The study uses both return in asset (ROA) and return on equity (ROE) as proxy for bank profitability. By employing balanced set of panel data and fixed effect model, the result shows that only real interest rate is positively related with profitability in regards to macroeconomic variables. In other words, an increase in real interest rate would lead to an increase in commercial profitability in Turkey. Ramadan [8] examines the determinants of bank performance of 10 Jordanian banks over the 2001-2010 periods. They discovered that both inflation and economic growth were found to be negatively insignificant on both return on assets (ROA) and return on equity (ROE) of the banks. However, Khwarush [7] which focusing more on determinants of commercial bank performance in Jordan for 2000-2010 periods found that both inflation rate and animal growth rate for gross commercial banks. 
Also, Demena [9], on the profitability determinants of Ethiopian commercial banks uses 10 years balance sheet data of 7 lending banks confirms positive effect of GDP, inflation and interest rate Determined and Anbarb [9] examines the bank-specific and, macroeconomic determinants of bank's profitability in Turkey over the time period from 2002 to 2010. The bank profitability is measured by return assets (ROA) and return on equity (ROE). Using a balanced panel database the results show that real interest rate affects the performance of banks positively, ("Banneceur and Houses, [12]. The Determinants if commercial bank interest Margin and profitability. Evidence from Tunisia and find that interest rate liberalization has constratung effect on net interest margins. In fact, partial liberalization had a negative impact on the interest margin whereas complete liberalization strengthens the ability of Tunisian banks to generate profit margins.

Rasheed [10] investigated interest rates determination in Nigeria by employing error correction model (ECM). The study found out that as the Nigeria financial sector integrated more global markets, returns on foreign assets will play a significant role in the determination of domestic interest rate. Felicia [1] used regression analysis to investigate the determinants of commercial banking lending behaviour in Nigeria. The study discovered that, commercial banks deposits have the greatest impacts on their lending behaviour.

Enyioku [11] examines the performance of banks in Nigeria based on the interest rate policies of the banks. The study analyzed published audited accounts of twenty (20) out of twenty five (25) banks that emerged from the consolidation exercise and data from the Central bank of Nigeria $(\mathrm{CBN})$. Applying regression and error correction methods to analyze the relationship between interest rates and bank performances if banks significantly. Aburine [12] used a sample of banks with 1255 individuals' observation on unbalanced panel data over the period 1980-2006 to investigate the macroeconomic determinants of bank profitability in Nigeria. The result revealed that real interest rate inflation, monetary policy and foreign exchange regime are positively associated with banks return on assets. Ahmed [5] reports that interest in loan as the largest constituent if income for Nigerian banks as evidenced from available data and that movement from one interest regime to another could have some effects on the profitability of banks in the system.

Uchendu [13] investigates the effect of monetary policies on the performance of Nigeria commercial banks. He found that the dominant factors influencing bank profitability are interest rates, exchange rate, bank reserves, banking structure and unit labour costs, particularly when return on capital is used as measure of profitability. He concludes that, stable and realistic monetary and banking policies are important for the profitability. He concluded that, stable and realistic monetary and banking policies are important for the profitability of commercial banking business in Nigeria.

\section{ReSEARCh Methodology \\ Research Design}

This study adopted ex post facto research design approach by investigating the effect of interest rate on the profitability of Nigerian deposit money banks.

\section{Method of Data Collection}

Data for this study were collected from secondary source. The data were extracted from the Central Bank of Nigeria Statistical Bulletin and the NDIC annual reports from 2004 - 2018. In addition to this, scholarly articles from academic journals and relevant textbooks were also consulted.

\section{Model Specification}

Specification of the Models was Subsequent to hypotheses conjectured to provide an analytical basis to test the validation or otherwise of the hypotheses. This was done by reducing the hypotheses to mathematical statements. Thus, the mathematical representations of the functional form that represent the stated hypotheses are expressed as follows:

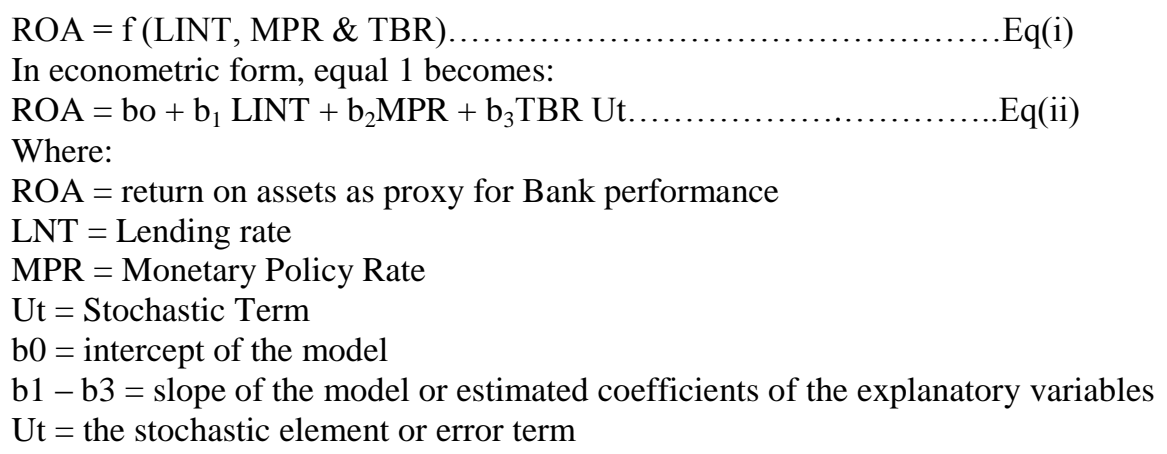




\section{MeTHOD OF DATA ANALYSIS}

The collected data in this study were analyzed using inferential statistics i.e Ordinary Least Square (OLS) regression analysis were carried out to examine the effect of interest rate on the profitability of money deposit banks in Nigeria. This analytical technique was chosen because of its property of producing Best Linear Unbiased Estimates (BLUE).

\section{Data Presentation and Analysis}

Table-1: Augmented-Dickney-Fuller Unit Root Test Results

Unit root test at logarithmic levels

$\mathrm{H} 0: \mathrm{b}=0$; Ha: $\mathrm{b}>0$

Table-1: Augmented-Dickney-Fuller Unit Root Test Results

\begin{tabular}{|l|l|l|l|l|}
\hline Variables & Critical value @ 5\% & ADF test statistics & Remarks & Order of Integration \\
\hline ROA & -2.960411 & 3.970495 & stationary & $I(0)$ \\
\hline LINR & -2.960411 & -2.995285 & stationary & $I(0)$ \\
\hline MPR & -2.960411 & -3.158877 & stationary & $I(0)$ \\
\hline TBR & -2.986225 & -3.140676 & stationary & $I(0)$ \\
\hline
\end{tabular}

Source: Author's Computation, 2020.

Table 1 reveals the outcome of the unit root test for the research variables. The result reveals that all the variables of interest are stationary at levels, suggesting that Ordinary Least Square is appropriate as estimator.

\section{Data Analysis and Discuss of Findings}

Table-2: OLS Regression Results

\begin{tabular}{|c|c|c|c|c|}
\hline \multicolumn{5}{|c|}{ Dependent Variable: ROA } \\
\hline \multicolumn{5}{|c|}{ Method: Least Squares } \\
\hline \multicolumn{5}{|c|}{ Date: 06/07/20 Time: 09:33 } \\
\hline \multicolumn{5}{|c|}{ Sample (adjusted): 20042018} \\
\hline \multicolumn{5}{|c|}{ Included observations: 12 after adjustments } \\
\hline Variable & Coefficient & Std. Error & t-Statistic & Prob. \\
\hline $\mathrm{C}$ & -0.269603 & 0.301260 & -0.894920 & 0.3970 \\
\hline LINT & 0.011117 & 0.017783 & 0.625129 & 0.5493 \\
\hline MPR & 0.011630 & 0.015414 & 0.754538 & 0.4722 \\
\hline TBR & 0.000259 & 0.015325 & 0.016895 & 0.9869 \\
\hline R-squared & 0.322812 & \multicolumn{2}{|c|}{ Mean dependent var } & 0.055983 \\
\hline Adjusted R-squared & 0.068867 & \multicolumn{2}{|c|}{ S.D. dependent var } & 0.074675 \\
\hline S.E. of regression & 0.072057 & \multicolumn{2}{|c|}{ Akaike info criterion } & -2.161507 \\
\hline Sum squared resid & 0.041538 & \multicolumn{2}{|c|}{ Schwarz criterion } & -1.999872 \\
\hline Log likelihood & 16.96904 & \multicolumn{2}{|c|}{ Hannan-Quinn criter. } & -2.221351 \\
\hline F-statistic & 1.271188 & \multicolumn{2}{|c|}{ Durbin-Watson stat } & 0.953207 \\
\hline Prob(F-statistic) & 0.347984 & & & \\
\hline
\end{tabular}

Obviously, the regression output on Table 2 shows the Durbin-Watson Statistics of 0.9532 which is less than the benchmark of 2 , although greater than the $\mathrm{R}^{2}$ value of 0.32 . Hence, there is presence of positive serial correlation which renders the estimated model result biased and hence, no meaningful economic and standard inference can be made. The auto-correlation problem needs to be corrected to avoid bias of OLS result. Therefore, the corrected version of the estimates is depicted in table 2.0: 
Table-3: Newey-West HAC-corrected OLS Estimates

\begin{tabular}{|c|c|c|c|c|}
\hline \multicolumn{3}{|c|}{ Dependent Variable: ROA } & & \\
\hline \multicolumn{3}{|c|}{ Method: Least Squares } & & \\
\hline \multicolumn{3}{|c|}{ Date: $06 / 07 / 20$ Time: 09:46 } & & \\
\hline \multicolumn{3}{|c|}{ Sample (adjusted): 20042018} & & \\
\hline \multicolumn{4}{|c|}{ Included observations: 12 after adjustments } & \\
\hline \multicolumn{5}{|c|}{ HAC standard errors \& covariance (Bartlett kernel, Newey-West fixed } \\
\hline \multicolumn{3}{|c|}{ bandwidth $=3.0000)$} & & \\
\hline Variable & Coefficient & Std. Error & t-Statistic & Prob. \\
\hline $\mathrm{C}$ & -0.269603 & 0.272487 & -0.989417 & 0.3514 \\
\hline LINT & 0.011117 & 0.015739 & 0.706302 & 0.5000 \\
\hline MPR & 0.011630 & 0.009831 & 1.183098 & 0.2707 \\
\hline TBR & 0.000259 & 0.008910 & 0.029060 & 0.9775 \\
\hline R-squared & 0.322812 & \multicolumn{2}{|c|}{ Mean dependent var } & 0.055983 \\
\hline Adjusted R-squared & 0.068867 & \multicolumn{2}{|c|}{ S.D. dependent var } & 0.074675 \\
\hline S.E. of regression & 0.072057 & \multicolumn{2}{|c|}{ Akaike info criterion } & -2.161507 \\
\hline Sum squared resid & 0.041538 & \multicolumn{2}{|c|}{ Schwarz criterion } & -1.999872 \\
\hline Log likelihood & 16.96904 & \multicolumn{2}{|c|}{ Hannan-Quinn criter. } & -2.221351 \\
\hline F-statistic & 1.271188 & \multicolumn{2}{|c|}{ Durbin-Watson stat } & 0.953207 \\
\hline Prob(F-statistic) & 0.347984 & \multicolumn{2}{|c|}{ Wald F-statistic } & 1.896128 \\
\hline Prob(Wald F-statistic) & 0.484023 & & & \\
\hline
\end{tabular}

Looking at the multiple linear regression results in Table 3, the regression equation predicting the linear relationship among the Return on assets of Nigerian banks (ROA), Lending interest rate (LINT), Monetary policy rate (MPR) and Treasury bill rate (TBR) can be stated as:

\begin{tabular}{|c|c|c|c|c|}
\hline $\mathrm{ROA}=$ & $-0.2696+$ & 0 011 I I & $00116 \mathrm{MP}$ & \\
\hline $\mathrm{E}$ & $(0.2725)$ & $(0.0157)$ & $(0.0098)$ & $(0.0089)$ \\
\hline T.ratios & $(-0.9894)$ & $(0.7063)$ & (1.1831) & $(0.0291)$ \\
\hline Prob. & $(0.3514)$ & $(0.5000)$ & $(0.2707)$ & $(0.9775)$ \\
\hline
\end{tabular}

The figures in the first set of parentheses are the estimated standard errors of the regression coefficients, the figures in the second set are estimated t-ratios, and the figures in the third set of parenthesis are the estimated p-values.

From the estimated regression model on Table 3, it showed that all the explanatory variables i.e lending interest rate (LINT), monetary policy rate(MPR), treasury bill rate(TBR) and ratio of cash balance to total liabilities maintained positive but insignificant relationships with the Return on assets of Nigerian banks (ROA). Therefore, $1 \%$ increase or decrease in LINT would resort to about $1.11 \%$ increase or decrease in the average or mean value of banks' profitability in Nigeria. Similarly, $1 \%$ increase in TBR would bring about $1.16 \%$ increase in the average or mean value of Return on assets of Nigerian banks and vice versa; also, $1 \%$ increase in monetary policy rate (MPR) would culminate in about $0.025 \%$ increase in ROA. Thus, all the explanatory variables conform to a priori expectation in terms of relationship with banks' profitability. The intercept of the model which was -0.2696 represented the value of the dependent variable (ROA) in billion naira should the explanatory variables be held constant.

The multiple correlation co-efficient $(\mathrm{R})$ which is the square root of $\mathrm{R}^{2}$ is 0.57 indicated a strong linear positive relationship between the independent variables (MPR, LINT and TBR) and the dependent variable which was the banks' profitability as proxied by Return on assets of Nigerian banks (ROA) since the value approached 1. Also, the coefficient of determination $\left(\mathrm{R}^{2}\right)$ of 0.32 indicated that about $32 \%$ of the variation in the dependent variable (ROA) could be explained by the independent variables while the remaining $68 \%$ was explained by other factors not captured in the model but represented by stochastic term. This figure portrayed the poorness of fit of the fitted regression model to the set of time series data. The $\mathrm{R}^{2}$ as adjusted for the degree of freedom (n-k) associated with the sums of squares entering into the specified model is 0.069 which was far from $\mathrm{R}^{2}$ value; this connoted that the model was affected by the addition or subtraction of variables from the estimated model. Furthermore, the standard error of 0.0720 was the standard deviation of the sampling distribution of the estimator which measured the precision of the estimates of the model and was relatively low as expected which undergirded the estimation accuracy of the coefficients.

T-ratios determines how large the coefficients will vary if carried out on repeated sampling MPR has the most significant t-ratios compare to LINT and TBR. It therefore meant that MPR would have very little variation in repeated sampling of the observations than other explanatory variables. F-stat of 2.27 with probability of 0.3479 as depicted on 
Table 3 revealed that jointly, the included independent variables failed to consistently and significantly explain variation in the dependent variable; that is, the percentage of variation in the dependent variable, accounted for by the explanatory variables may be due to chance or error.

\section{Test of Hypotheses}

The decision rule for testing hypothesis is that Null Hypothesis (H0) should be rejected and Alternate Hypothesis (H1) accepted if P-value is less than 0.05 and vice versa.

$\mathbf{H 0}_{1}$ : Lending interest rate has no significant effect on the return on assets of Nigerian banks;

$\mathbf{H 1}_{1}$ : Lending interest rate has significant effect on return on assets of Nigerian banks;

Since P-value of 0.5000 was less than the critical value of 0.05 , there was no enough reason to reject $\mathrm{H} 0_{1}$, therefore, lending interest rate has no significant effect on the Nigerian banks' profitability. This implied that during the period under study, interest rate earned by the banks on their credits contributed to the increase in the banks' profit but at a low rate.

$\mathbf{H O}_{2}$ : Monetary policy rate has no significant effect on return on assets of Nigerian banks.

$\mathbf{H 1}_{2}$ : Monetary policy rate has significant effect on return on assets of Nigerian banks

Here also, P-value of 0.2707 was less than the critical value of 0.05 ; thus, there was no enough reason to reject the $\mathrm{HO}_{2}$, hence, monetary policy rate has no significant positive effect on the Nigerian banks' profitability.

$\mathbf{H O}_{3}$ : Treasury bill rate has no significant effect on the return on assets of Nigerian banks

H1 $_{3}$ : Treasury bill rate has significant effect on the return on assets of Nigerian banks;

In the same manner, Treasury bill rate has P-value of 0.9775 which was obviously less than the critical value of 0.05; thus, there was no enough reason to reject the $\mathrm{H}_{3}$. Hence, Treasury bill rate has no significant effect on the Nigerian banks' profitability.

\section{CONCLUSIONS AND RECOMMENDATIONS Conclusion}

This study has investigated the effect of lending interest rate on the profitability of banks in Nigeria between 2004 and 2018. Where the environment is conducive and supportive, profitability of the banks is enhanced and good lending behavior is guaranteed. Meanwhile, where the operating environment is however, harsh and unstable, banks' profitability is bound to suffer. Thus, banks must understand that they need to do a lot in order to ensure good lending behavior even where a good measure of macro-economic stability is achievable. In this study, majority of the proxies of lending interest rate appeared to be insignificant against the proxy of banks' profitability (ROA). Based on the findings of this study as discussed above, it was concluded that lending interest rate of banks has weak but positive effect on their profitability because the p-values of the explanatory variables as indicated in Table 2 and 3 respectively are statistically significance.

\section{RECOMMENDATIONS}

Following the findings of this study, the following recommendations were made:

i. Banks should conduct a thorough appraisal of their lending interest rate from time to time to ensure that they significantly increases their profit level without sacrificing affordability to their customers.

ii. Banks must strike a good balance in their loans pricing and investment decisions as this will help them to cover cost associated with lending while maintaining good banking relationship with their customers.

iii. There is need to strengthen both the monetary policy rate which is the fundamental determinant of the banks' lending interest rate to ensure that it is in line with macro-economic objective of the government.

\section{REFERENCES}

1. Felicia, O. O. (2011). Determinats of Commercial Banks Lending Behaviour in Nigeria. International Journal of Financial Research, 2(2): 1-12.

2. Pandey, M. (1999). A Multi-Objective Lending and Credit Administration Model for Commercial Banks. Nigerian Financial Review, 4(2): 55-60.

3. Patnaik, I., \& Vasudrvan, D. (1998). Interest Rate Determination: An Error Correction Model, National Council Appl. Econs. Res. New Delhi. 110002.

4. Ewert, R., Szczesmy, A., \& Schenk, G. (2000). Determinants of Bank Lending Performance in Germany. Schmalenbanch Business Review (SBR), 52:344-362.

5. Kanwal \& Nadeem. (2003). The Impact of Macroeconomic Variables on the Profitability of Listed Commercial Banks in Pakistan. European Journal of Business ans Social Sciences, 2(9), 186-201. 
6. RazlanYusoff, A., Suffian, M. R. Z., \& Taib, M. Y. (2011). Literature review of optimization technique for chatter suppression in machining. Journal of Mechanical Engineering and Sciences (JMES), 1, 47-61.

7. Khrawish, H.A. (2011). "Determinants of Commercial Banks Performance: Evidence from Jordan. International Research Journal of Finance and Economics, 5(7)1450-288.

8. Ramadan, M. F. (2011). Bioactive phytochemicals, nutritional value, and functional properties of cape gooseberry (Physalis peruviana): An overview. Food Research International, 44(7), 1830-1836.

9. Demena, B. A. (2011). Determinants of fish catch levels in artisanal fishing in Eritrea. Masters of Arts in Development Studies Research Paper, Institute of Social Studies, The Hague, The Netherlands November.

10. Rasheed, Z. A., Yang, J., Wang, Q., Kowalski, J., Freed, I., Murter, C., ... \& Goggins, M. (2010). Prognostic significance of tumorigenic cells with mesenchymal features in pancreatic adenocarcinoma. Journal of the National Cancer Institute, 102(5), 340-351.

11. Enyioku, N. (2012). Impact of Interest Rate Policy and Performance of Deposit Money Banks in Nigeria. Global. Journal of Management and Business Research, 12 (21), 2249-4588.

12. Aburime, T. (2008). Determinants of bank profitability: Company-level evidence from Nigeria. Available at SSRN 1106825

13. Uchendu, O. (1995). Monetary Policy and the Performance of Commercial Banks in Nigeria. Central Bank of Nigeria Economic and Financial Review, 33(2), 156-170.

14. Anyanwu, J. C. (1997). The structure of the Nigerian economy (1960-1997). Joanee educational publishers.

15. Stiglitz, J. E., \& Weiss, A. (1981). Credit rationing in markets with imperfect information. The American economic review, 71(3), 393-410.

16. Chodecal, D. (2004). Impact of lending policy on banking industry in Nigeria. Journal of Banking and Finance, 7(1), 12-22.

17. Ongena, S., \& Smith, D.C. (2000). What Determines the Number of Bank Relationships: Cross Country Evidence. Journal of Financial Intermediation, 9(5): 26-56.

18. Karceski, J. Ongena, S., \& Smith, D.C. (2004). The Impact of Bank Consolidation on Commercial Borrower Welfare. Journal of Finance, 60(4): 2043-2082.

19. Ezirim, U. (2005). Prudential Regulation of Nigerian Banking, Lagos: University of Lagos Press. 67-89. 